only minor deviations from the line $\eta=\eta$ will occur. Plotting $1 / \eta$ against $1 / T$ clearly shows that the experimental data obtained here do not fit the equation proposed by Dr. A. V. Brancker.

The Geigy Co., Ltd.,

Physical Laboratory, Tenax Road,

Manchester 17. Dec. 21.

' Nature, 166, 905 (1950).

\section{Temporary Reduction of Viscosity of Liquids at High Rates of Shear}

IN view of a recent statement" "that solutions of macromolecular substances may show an anomalous fall in the coefficient of viscosity at high rates of shear", it is emphasized once again ${ }^{2}$ that, at sufficiently high rates of shear, any liquid consisting of elongated molecules must be expected to exhibit a decrease of the coefficient of viscosity with increasing rate of shear. This means that there is only a quantitative, but no qualitative, difference between the dependence of viscosity on rate of shear of so-called Newtonian liquids and that of solutions of macromolecular substances. Grunberg and Nissan ${ }^{3}$ estimated that at a rate of shear of about $10^{\circ}$ sec. $^{-1}$ pentane might begin to show an appreciable reduction of viscosity, and Bondi ${ }^{4}$ predicted that temporary reductions of viscosity would become apparent for shearing stresses of more than $10^{5}$ dynes $/ \mathrm{cm} .^{2}$ for straight hydrocarbon chains with molecular weights of 500 and more. In addition to our own previouis results on castor oil and straight mineral oils ${ }^{5}$, experimental evidence is now prosented to prove that a chemically defined liquid, such as tetradecane, suffers an appreciable fall of its coefficient of viscosity over a range of rates of shear extending to about 350,000 sec. ${ }^{-1}$.

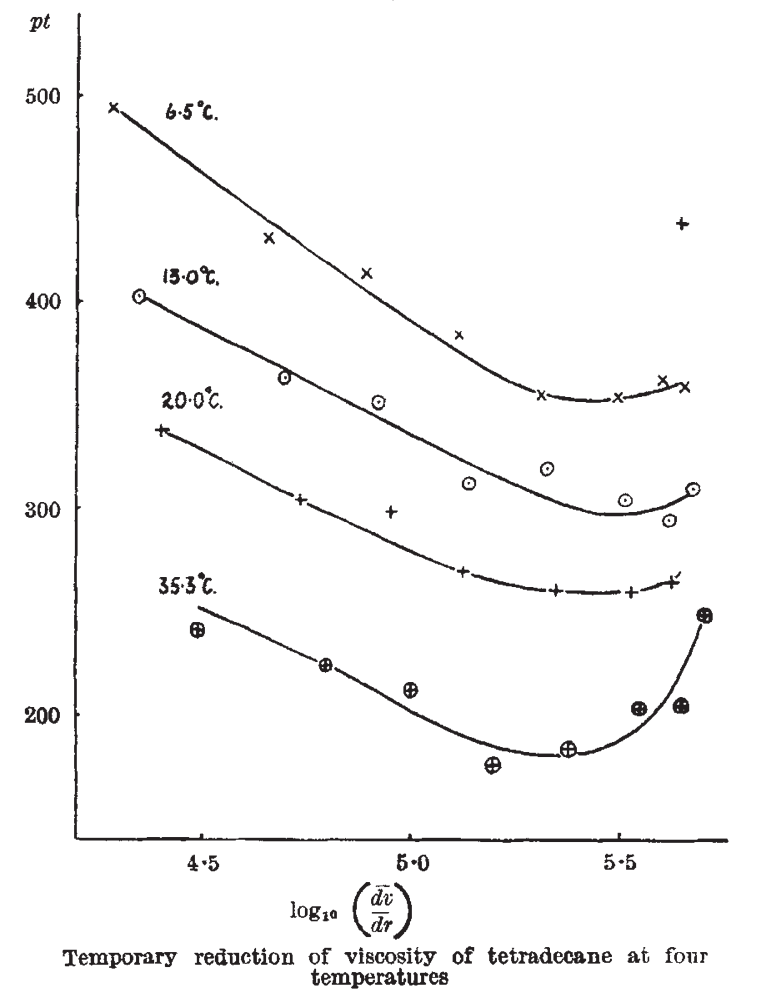

The experimental difficulty mentioned by Ward, Neale and Bilton ${ }^{1}$ of keeping the temperature constant at high rates of shear is avoided by the use of a jet viscometer (enclosed in a temperature jacket to enable one to vary the temperature at which the measurements are taken), where even at the highest rate of shear the total pressure-volume energy converted into heat would produce a rise in temperature of the liquid of only $0.05^{\circ} \mathrm{C} .{ }^{2}$, and this temperature rise is constant over the entire cross-section of the short capillary.

The accompanying diagram and Table 1 show results with tetradecane at four temperatures. In the diagram, the corrected value of the product of the given pressure difference $p$ (in cm. mercury) along the short capillary (of radius $r$ ) by the time $t$ of efflux of a given volume $V$ of liquid is plotted against the rate of shear calculated from Poiseuille's equation, that is, $\left(\frac{\overline{d v}}{d r}\right)=\frac{4 V}{\pi r^{3} t}$.

Table 1. TEMPorary REDUCTION OF VISCOSITY OF TETRADRoANE

\begin{tabular}{|c|c|c|c|}
\hline $\begin{array}{c}\text { Temperature } \\
\text { ( }{ }^{\circ} \text { C.) }\end{array}$ & $\begin{array}{c}\text { Low rate of } \\
\text { shear viscosity } \\
\text { (poises) }\end{array}$ & $\begin{array}{c}\text { Rate of } \\
\text { shear } \\
\text { (sec-1 }\end{array}$ & $\begin{array}{c}\text { Percentage } \\
\text { temporary } \\
\text { viscosity reduction }\end{array}$ \\
\hline $6 \cdot 5$ & $3 \cdot 2 \times 10^{-2}$ & 263,000 & 28.1 \\
$13 \cdot 0$ & $2 \cdot 712 \times 10^{-2}$ & 369,800 & 25 \\
$20 \cdot 0$ & $2 \cdot 322 \times 10^{-2}$ & 281,800 & $23 \cdot 6$ \\
$35 \cdot 3$ & $1.811 \times 10^{-2}$ & 223,800 & $24 \cdot 3$ \\
\hline
\end{tabular}

Owing to the comparatively low viscosity of tetra. decane, the present results include the theoretical kinetic energy correction modified by an empirical factor based on Schiller and Kirsten's $\mathrm{s}^{7} l / 2 r=0.029 R$ criterion ( $R=$ Reynolds's number) for the minimum length of tube, in order that Poiseuille's equation may be applied, as outlined elsewhere ${ }^{5}$.

Table 2. TEMPorary Viscosity REDUCTYON OF VArious orts

\begin{tabular}{|c|c|c|c|c|}
\hline Material & $\begin{array}{l}\text { Temper- } \\
\text { ature } \\
\left({ }^{\circ} \mathrm{C} .\right)\end{array}$ & $\begin{array}{l}\text { Low rate of } \\
\text { shear viscosity } \\
\text { (poises) }\end{array}$ & $\begin{array}{l}\text { Rate of } \\
\text { shear } \\
\left(\text { sec.-1 }^{-1}\right\rangle\end{array}$ & $\begin{array}{l}\text { Percentage } \\
\text { temporary } \\
\text { viscosity } \\
\text { reduction }\end{array}$ \\
\hline Castor oil & $100 \cdot 1$ & $21.8 \times 10^{-2}$ & 234,700 & $24 \cdot 4$ \\
\hline liquid paraffin & $56 \cdot 1$ & $28.6 \times 10^{-2}$ & 182,300 & $17 \cdot 1$ \\
\hline $\begin{array}{l}A 30 \text { trans" } \\
\text { former oil } \\
\text { Straight min- } \\
\text { eral oil " } G \text { " }\end{array}$ & $\begin{array}{r}20 \cdot 0 \\
100 \cdot 0 \\
75 \cdot 0\end{array}$ & $\begin{array}{ll}21 & \times 10^{-2} \\
14 \cdot 4 & \times 10^{-2} \\
37 \cdot 7 & \times 10^{-2}\end{array}$ & $\begin{array}{l}228,000 \\
282,000 \\
146,000\end{array}$ & $\begin{array}{l}18 \cdot 0 \\
26 \cdot 8 \\
14 \cdot 7\end{array}$ \\
\hline $\begin{array}{l}\text { Iight mineral } \\
\text { oil " } A \text { " }\end{array}$ & $13 \cdot 6$ & $5.59 \times 10^{-2}$ & $1.34,900$ & $20 \cdot 6$ \\
\hline
\end{tabular}

Since the results with tetradecane are similar to those obtained with a variety of oils free from macromolecular additions (Table 2), it is clear that tem. porary viscosity reductions can be obtained with any type of liquid, including the so-called Newtonian liquids. High rates of shear are better defined with the jet viscometer $r^{8}$ than with a rotational viscometer, where eccentricity and vibrations have a disturbing influence.

W. J. MORRIS

R. SchNurmanN

Physics Department,

Manchester Oil Refinery, Ltd., Manchester. Dec. 4.

${ }^{1}$ Ward, A. F. H., Neale, S. M., and Bitton, N. F., Nature, 168, 905 $(1950)$.

"Schnurmann, R., and Morris, W. J., "Principles of Rheological Grunberg, I., and Nissan, A, H., Nature,

+ Bondi, A., J. App. Phys., 16, 539 (1945).

s Schnurmann, R., Proc. Int. Rheol. Congr. Holland, 1948, Pt. 2, 142.

'Morris, W. J., and Schnurmann, R., Rev. Sci. Instr., 17, 17 (1946).

'Schiller, L., and Kirsten, H., Phys. Z., 22, 523 (1921).

"Morris, W. J., "Jet Viscometers for High Rates of Shear", M.Sc. 